RASĀYAN J. Chem.

Vol. 13 | No. 1 |298 - 305| January - March | 2020 ISSN: 0974-1496 | e-ISSN: 0976-0083 | CODEN: RJCABP

RJC http://www.rasayanjournal.com http://www.rasayanjournal.co.in

\title{
SYNTHESIS OF $\mathrm{MgFe}_{2} \mathrm{O}_{4}$-MgO NANOCOMPOSITE: INFLUENCE OF MgO ON THE CATALYTIC ACTIVITY OF MAGNESIUM FERRITE IN BIODIESEL PRODUCTION
}

\author{
Helmiyati", G.H. Abbas, Y. Budiman and S. Ramadhani \\ Department of Chemistry, Faculty of Mathematics and Natural Sciences, University of \\ Indonesia, Depok 16424, Indonesia \\ *E-mail: helmiyati@sci.ui.ac.id
}

\begin{abstract}
A novel magnetic solid base catalyst consisting of an $\mathrm{MgFe}_{2} \mathrm{O}_{4}-\mathrm{MgO}$ nanocomposite was successfully prepared by synthesizing magnesium ferrite $\left(\mathrm{MgFe}_{2} \mathrm{O}_{4}\right)$ as the catalyst support, and it was employed in an esterification reaction for the production of biodiesel. $\mathrm{MgFe}_{2} \mathrm{O}_{4}$ was synthesized by a ball-milling mechanochemical method at various furnace temperatures $\left(350^{\circ} \mathrm{C}, 550^{\circ} \mathrm{C}\right.$ and $\left.750^{\circ} \mathrm{C}\right)$, and the best results were obtained at $750^{\circ} \mathrm{C}$. The results of TEM revealed an average size of $39 \mathrm{~nm}$. A nanocomposite of $\mathrm{MgFe}_{2} \mathrm{O}_{4}-\mathrm{MgO}$ was successfully synthesized in this study, as confirmed by Fourier transform infrared (FTIR), X-ray diffraction (XRD), scanning electron microscopy-energy dispersive $\mathrm{X}$-ray (SEM-EDX) and transmission electron microscopy (TEM) characterization. The results of the FTIR characterization revealed peaks with wavenumbers corresponding to $\mathrm{Mg}-\mathrm{O}$ and $\mathrm{Fe}-\mathrm{O}$ bonds in the range of 500-900 $\mathrm{cm}^{-1}$, SEM mapping showed that $\mathrm{MgO}$ was distributed on the surface of the $\mathrm{MgFe}_{2} \mathrm{O}_{4}$ catalyst support, and the $\mathrm{MgFe}_{2} \mathrm{O}_{4}-\mathrm{MgO}$ average size was found to be $50 \mathrm{~nm}$ by TEM. The influence of $\mathrm{MgO}$ on $\mathrm{MgFe}_{2} \mathrm{O}_{4}$ was determined by varying the molar ratio of $\mathrm{MgFe}_{2} \mathrm{O}_{4}$ to $\mathrm{MgO}$ from 1:1,1:2 and 1:3 and by studying the catalytic activity in the esterification of oleic acid to biodiesel. The best $\mathrm{MgFe}_{2} \mathrm{O}_{4}-\mathrm{MgO}$ nanocomposite have a molar ratio of 1: 2 and gave a percent conversion of $96.089 \%$. Impregnating $\mathrm{MgFe}_{2} \mathrm{O}_{4}$ with $\mathrm{MgO}$ increased the number of basic active sites, thereby increasing the catalytic activity. This type of nanocomposite is a promising new material for future catalysts. Keywords: Biodiesel, Catalyst, Magnesium Ferrite, Nanocomposite, Oleic Acid
\end{abstract}

(C) RASĀYAN. All rights reserved

\section{INTRODUCTION}

Renewable fuels such as biodiesel are one of the alternative energy sources that can overcome the limitations of nonrenewable energy resources. ${ }^{1,2,3}$ Compared to fossil fuels, the use of biodiesel can reduce the hydrocarbons and particulates in exhaust emissions by $70 \%$ and $50 \%$, respectively, and $\mathrm{CO}_{2}$ emissions by $78 \%$ due to its renewable nature. ${ }^{4}$ Biodiesel is a mixture consisting of fatty acid methyl esters (FAMEs) generally derived from methyl and ethyl alcohol. Catalysts are currently being developed to improve the efficiency of biodiesel production. ${ }^{5}$

Alkaline catalysts have higher catalytic activities than acid catalysts in transesterification reactions. ${ }^{6}$ Heterogeneous solid base catalysts, such as the metal oxides $\mathrm{MgO}^{7}, \mathrm{CaO} / \mathrm{SiO}_{2}{ }^{1}, \mathrm{MgO} / \mathrm{Li}_{2} \mathrm{O}^{8}, \mathrm{ZrO}_{2}{ }^{9}$, $\mathrm{NiO} / \mathrm{CNZ}^{10}$, etc., have been widely used in various studies to synthesize biodiesel. Although these heterogeneous catalysts are advantageous in terms of catalyst separation and pollution reduction, most of them have limited catalytic activity and stability. ${ }^{11}$

Bimetallic catalysts, such as ferrite metal $\left(\mathrm{XFe}_{2} \mathrm{O}_{4}\right)$, where $\mathrm{X}$ is a divalent metal cation, are of significant interest to many researchers because of their unique magnetic properties, thermal and structural stabilities, and higher catalytic activities than monometallic oxides. ${ }^{6,12}$ Therefore, in this study, a nanocomposite was synthesized by impregnating $\mathrm{MgFe}_{2} \mathrm{O}_{4}$, which has acid sites, with $\mathrm{MgO}$, which has basic sites, according to the previous studies ${ }^{6}$, with modifications based on mechanochemical methods. ${ }^{13}$

In particular, ball-milling mechanochemistry was employed in this work as a simple and low-cost methodology. The synthesized products were characterized by FTIR, XRD, SEM-EDX and TEM. The

Rasayan J. Chem., 13(1), 298-305(2020)

http://dx.doi.org/10.31788/RJC.2020.1315497

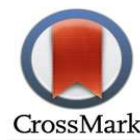


catalytic activity of the catalyst in the esterification of oleic acid to fatty acid methyl esters (FAMEs) was determined according to our previous studies. ${ }^{2,14,16}$ The amount of residual acid remaining after the esterification reaction was then measured to determine the percent conversion to biodiesel.

\section{EXPERIMENTAL}

\section{Materials}

The chemicals were analytical grade and used without further purification. $\mathrm{Mg}\left(\mathrm{NO}_{3}\right)_{2} \cdot 6 \mathrm{H}_{2} \mathrm{O}$, $\mathrm{Fe}\left(\mathrm{NO}_{3}\right)_{3} \cdot 9 \mathrm{H}_{2} \mathrm{O}$, urea, oleic acid and methanol (98\%) were all purchased from Merck.

\section{Synthesis of the $\mathrm{MgFe}_{2} \mathrm{O}_{4}$ and $\mathrm{MgFe}_{2} \mathrm{O}_{4} / \mathrm{MgO}$ Nanocomposites}

The synthesis of the $\mathrm{MgFe}_{2} \mathrm{O}_{4}$ nanocomposite in this study was based on previous literature methods ${ }^{5}$ with mechanochemical modifications ${ }^{13}$. In this work, ball-milling mechanochemistry was performed using a hard small ball. The first stage, the synthesis of $\mathrm{MgFe}_{2} \mathrm{O}_{4}$, involved mixing a given amount of $\mathrm{Mg}\left(\mathrm{NO}_{3}\right)_{2} \cdot 6 \mathrm{H}_{2} \mathrm{O}$ with $\mathrm{Fe}\left(\mathrm{NO}_{3}\right)_{3} \cdot 9 \mathrm{H}_{2} \mathrm{O}$ and then adding a urea solution. The mixture was heated at $70^{\circ} \mathrm{C}$ and stirred by ball milling until a brown gel was obtained. Then, the mixture was calcined at various temperatures $\left(350^{\circ} \mathrm{C}, 550^{\circ} \mathrm{C}\right.$ and $\left.750^{\circ} \mathrm{C}\right)$ in a furnace for 3 hours. The resulting reddish-brown precipitate was $\mathrm{MgFe}_{2} \mathrm{O}_{4}$, and it was characterized by FTIR, XRD, SEM-EDX and TEM.

In the second stage, a given amount of $\mathrm{Mg}\left(\mathrm{NO}_{3}\right)_{2} \cdot 6 \mathrm{H}_{2} \mathrm{O}$ was dissolved in a urea solution, and then $\mathrm{MgFe}_{2} \mathrm{O}_{4}$ was added in various molar ratios $(1: 1,1: 2,1: 3)$ at $80^{\circ} \mathrm{C}$. The mixture was stirred at a medium speed to give a precipitate, which was subsequently dried in an oven at $110^{\circ} \mathrm{C}$ for 24 hours. Furthermore, the precipitate was calcined in a furnace at a temperature of $550^{\circ} \mathrm{C}$ for 4 hours. A reddish brown $\mathrm{MgFe}_{2} \mathrm{O}_{4} / \mathrm{MgO}$ nanocomposite was obtained and characterized by FTIR, XRD and SEM mapping.

\section{Catalytic Activity}

The catalytic activity of the $\mathrm{MgFe}_{2} \mathrm{O}_{4} / \mathrm{MgO}$ nanocomposite in the esterification of oleic acid with methanol to biodiesel was evaluated using a batch method. The esterification reaction was performed at $60^{\circ} \mathrm{C}$ for 3 hours with a ratio of oleic acid to methanol of $1: 12$ and $0.1 \mathrm{~g}$ catalyst. In this study, the percent conversion was determined by calculating the acid number, or free fatty acids (FFAs). The acid numbers were determined by an acid-base titration method using $0.1 \mathrm{~N} \mathrm{KOH}$. The acid number was calculated using the following equations (1) and (2). ${ }^{15,16}$

$$
\begin{aligned}
& F F A=\frac{V_{K O H} \times N_{K O H} \times M r_{K O H}}{\text { sample mass }} \\
& \text { Conversion }(\%)=\frac{F F A_{\text {initial }}-F F A_{\text {final }}}{F F A_{\text {initial }}} \times 100
\end{aligned}
$$

Where FFA is the free fatty acid number, FFA initial is the FFA oleic acid number, and FFA final is the FFA number after the esterification reaction.

\section{Composite of $\mathrm{MgFe}_{2} \mathrm{O}_{4}$}

\section{RESULTS AND DISCUSSION}

Magnesium ferrite $\left(\mathrm{MgFe}_{2} \mathrm{O}_{4}\right)$ is successfully synthesized with a reddish-brown color and is paramagnetic in accordance with the previous studies ${ }^{6}$.

The proposed formation reaction of magnesium ferrite is as follows.

In the first stage, urea is ionized in water and then decomposes into $\mathrm{NH}_{3}$ and $\mathrm{CO}_{2}$ gas as shown in equation (3):

$$
\mathrm{NH}_{2} \mathrm{CONH}_{2(s)}+\mathrm{H}_{2} \mathrm{O}_{(a q)} \rightarrow 2 \mathrm{NH}_{3(a q)}+\mathrm{CO}_{2(g)}
$$

Furthermore, the reaction of ammonia with water gives ammonium hydroxide, as shown in equation (4):

$$
\mathrm{NH}_{3(a q)}+\mathrm{H}_{2} \mathrm{O}_{(a q)} \rightarrow \mathrm{NH}_{4} \mathrm{OH}_{(a q)}
$$

Ammonium hydroxide is then ionized into ammonium $\left(\mathrm{NH}_{4}{ }^{+}\right)$and hydroxide $\left(\mathrm{OH}^{-}\right)$ions, as in equation (5):

$$
\mathrm{NH}_{4} \mathrm{OH}_{(a q)} \rightleftharpoons \mathrm{NH}_{4(a q)}^{+}+\mathrm{OH}_{(a q)}^{-}
$$


RASĀYAN J. Chem.

Vol. 13 | No. 1 |298 - 305| January - March | 2020

The $\mathrm{Fe}\left(\mathrm{NO}_{3}\right)_{3} \cdot 9 \mathrm{H}_{2} \mathrm{O}$ and $\mathrm{Mg}\left(\mathrm{NO}_{3}\right)_{2} \cdot 6 \mathrm{H}_{2} \mathrm{O}$ precursors are ionized to $\mathrm{Fe}^{3+}$ and $\mathrm{Mg}^{2+}$ ions in water, as shown in equations (6) and (7), respectively:

$$
\begin{aligned}
& \mathrm{Fe}\left(\mathrm{NO}_{3}\right)_{3} \cdot 9 \mathrm{H}_{2} \mathrm{O}_{(s)} \rightarrow \mathrm{Fe}^{3+}{ }_{(a q)}+3 \mathrm{NO}_{3}^{-}{ }_{(a q)}+9 \mathrm{H}_{2} \mathrm{O}_{(a q)} \\
& \mathrm{Mg}\left(\mathrm{NO}_{3}\right)_{2} \cdot 6 \mathrm{H}_{2} \mathrm{O}_{(\mathrm{S})} \rightarrow \mathrm{Mg}^{2+}{ }_{(a q)}+2 \mathrm{NO}_{3}^{-}{ }_{(a q)}+6 \mathrm{H}_{2} \mathrm{O}_{(a q)}
\end{aligned}
$$

The hydroxide ions in equation (5) react with the $\mathrm{Fe}^{3+}$ and $\mathrm{Mg}^{2+}$ ions to give $\mathrm{Fe}(\mathrm{OH})_{3}$ and $\mathrm{Mg}(\mathrm{OH})_{2}$ in equations (8) and (9), respectively:

$$
\begin{aligned}
& \mathrm{Fe}^{3+}{ }_{(a q)}+3 \mathrm{OH}^{-}{ }_{(a q)} \rightleftharpoons \mathrm{Fe}(\mathrm{OH})_{3(s)} \\
& \mathrm{Mg}^{2+}{ }_{(a q)}+\mathrm{OH}^{-}{ }_{(a q)} \rightleftharpoons \mathrm{Mg}(\mathrm{OH})_{2(s)}
\end{aligned}
$$

In the last step, $\mathrm{Fe}(\mathrm{OH})_{3}$ decomposes into $\alpha-\mathrm{Fe}_{2} \mathrm{O}_{3}$ at high temperatures, and then $\alpha-\mathrm{Fe}_{2} \mathrm{O}_{3}$ reacts with $\mathrm{Mg}(\mathrm{OH})_{2}$ to form $\mathrm{MgFe}_{2} \mathrm{O}_{4}$, as shown in equations (10) and (11):

$$
\begin{aligned}
& 2 \mathrm{Fe}(\mathrm{OH})_{3(s)} \rightarrow \alpha-\mathrm{Fe}_{2} \mathrm{O}_{3(s)}+3 \mathrm{H}_{2} \mathrm{O}_{(g)} \\
& \alpha-\mathrm{Fe}_{2} \mathrm{O}_{3(s)}+\mathrm{Mg}(\mathrm{OH})_{2(s)} \rightarrow \mathrm{MgFe}_{2} \mathrm{O}_{4(s)}
\end{aligned}
$$

The resulting $\mathrm{MgFe}_{2} \mathrm{O}_{4}$ has magnetic properties that are observable using external magnets.

\section{FTIR Analysis of Magnesium Ferrite $\left(\mathrm{MgFe}_{2} \mathrm{O}_{4}\right)$}

Figure-1 shows the FTIR spectra of magnesium ferrite $\left(\mathrm{MgFe}_{2} \mathrm{O}_{4}\right)$ obtained at furnace temperatures of $350^{\circ} \mathrm{C}$ (Fig.-1a), $550^{\circ} \mathrm{C}$ (Fig.-1b), and $750^{\circ} \mathrm{C}$ (Fig.-1c). In all the spectra, peaks are observed at wavenumbers in the range of $475-700 \mathrm{~cm}^{-1}$, indicating the presence of $\mathrm{Mg}-\mathrm{O}$ and $\mathrm{Fe}-\mathrm{O}$ bonds ${ }^{5}$. In Fig.1c, a sharp peak appears at $1522 \mathrm{~cm}^{-1}$ due to $\mathrm{NO}_{3}$ groups, which reveals that the precursor does not burn completely in the calcination process. The peak at $1642 \mathrm{~cm}^{-1}$ is a specific absorption of the $\mathrm{C}=\mathrm{O}$ group of the remaining urea $\left(\mathrm{CO}\left(\mathrm{NH}_{2}\right)_{2}\right)$. The peaks approximately $3000-3800 \mathrm{~cm}^{-1}$ are attributed to the O-H stretching of the remaining $\mathrm{Mg}(\mathrm{OH})_{2}$ and $\mathrm{Fe}(\mathrm{OH})_{3}$ that do not decompose into $\mathrm{MgFe}_{2} \mathrm{O}_{4}$ and of water vapor absorbed by the sample. The peak in Fig.-1a is lower than those in Fig.-1b and 1c, indicating that fewer impurities remain after calcination at $750^{\circ} \mathrm{C}$ than after calcination at $350^{\circ} \mathrm{C}$ and $550^{\circ} \mathrm{C}$.

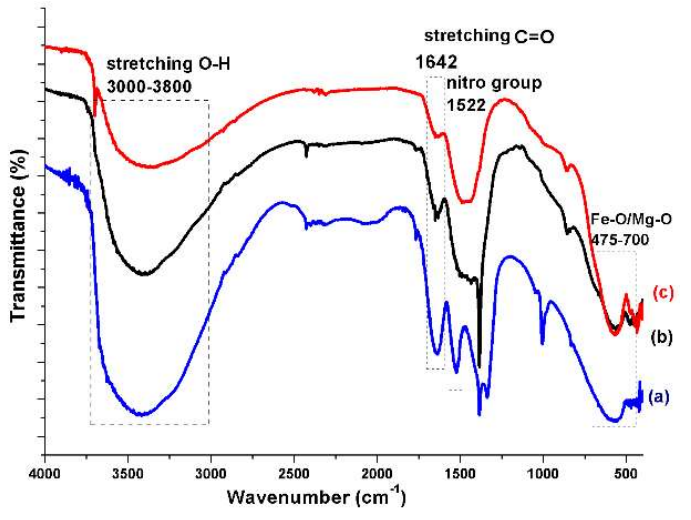

Fig.-1: FTIR Spectra of $\mathrm{MgFe}_{2} \mathrm{O}_{4}$ Obtained at Different Temperatures

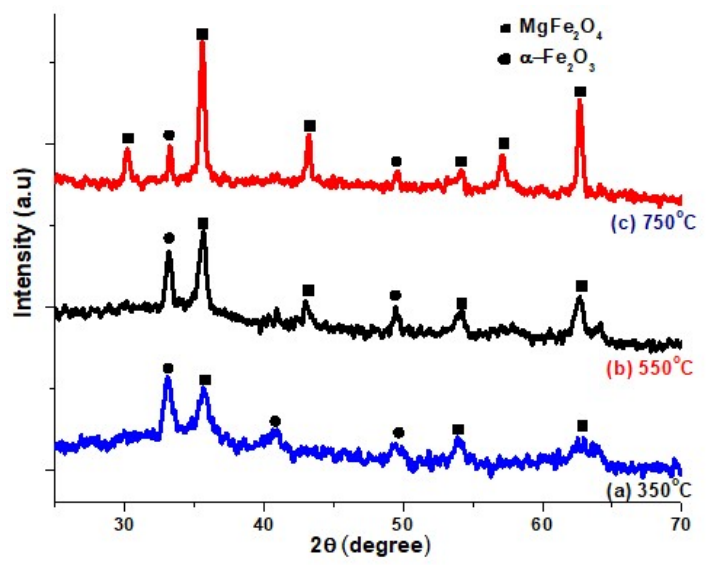

Fig.-2: XRD Patterns of $\mathrm{MgFe}_{2} \mathrm{O}_{4}$ Obtained at Different Temperatures

\section{XRD Analysis of $\mathrm{MgFe}_{2} \mathrm{O}_{4}$}

Figure-2 shows the XRD patterns of $\mathrm{MgFe}_{2} \mathrm{O}_{4}$ at various furnace temperatures $\left(350^{\circ} \mathrm{C}\right.$ (Fig.-2a), $550^{\circ} \mathrm{C}$ (Fig.-2b) and $750^{\circ} \mathrm{C}$ (Fig.-2c). At furnace temperatures of $350^{\circ} \mathrm{C}$ and $550^{\circ} \mathrm{C}$ (Fig.-2a and $2 \mathrm{~b}$, respectively), peaks due to $\alpha-\mathrm{Fe}_{2} \mathrm{O}_{3}$ (sphere shape) are observed because some $\alpha-\mathrm{Fe}_{2} \mathrm{O}_{3}$ does not decompose into $\mathrm{MgFe}_{2} \mathrm{O}_{4}$, whereas at a furnace temperature of $750^{\circ} \mathrm{C}$ (Fig.-2c), $2 \theta$ peaks are observed at $30.2^{\circ}, 33.2^{\circ}, 35.5^{\circ}, 43.3^{\circ}, 54.1^{\circ}, 57.0^{\circ}$, and $62.6^{\circ}$, which is in accordance with JCPDS 01-073-2211 for the crystalline phase of $\mathrm{MgFe}_{2} \mathrm{O}_{4}$ (square shape). This result shows that $\mathrm{MgFe}_{2} \mathrm{O}_{4}$ is successfully 
RASĀYAN J. Chem.

Vol. 13 | No. 1 | 298 - 305| January - March | 2020

synthesized at a furnace temperature of $750^{\circ} \mathrm{C}$. The XRD results are consistent with the FTIR data. The peaks observed in the results of this study are also similar to those observed in a previous study ${ }^{6}$.

\section{SEM-EDX Analysis of $\mathrm{MgFe}_{2} \mathrm{O}_{4}$}

Figure-3a shows a micrograph of $\mathrm{MgFe}_{2} \mathrm{O}_{4}$ with a nanospherical shape and rough surface morphology. The surface morphology and shape of $\mathrm{MgFe}_{2} \mathrm{O}_{4}$ are similar to those observed in previous studies ${ }^{17,18}$. SEM-EDX analysis was performed to determine the mass percent of each element in the synthesized compound, as shown in Fig.-3b. The compositions of $\mathrm{Mg}, \mathrm{Fe}$ and $\mathrm{O}$ are 12.1, 47.8 and 40.2 wt.\%, respectively. To support the SEM-EDX results, the percentage of mass was calculated using equation (12), and the calculated results for the elemental mass percentages of $\mathrm{Mg}, \mathrm{Fe}$ and $\mathrm{O}$ are interpreted in Fig.-3c.

$$
\text { Element Mass Percentage (\%) } \frac{\text { Ar element }}{\text { Mr Compound }} \times 100 \%
$$

Figure-3c shows the elemental mass percentages in this study compared with the theoretical mass percentages of $\mathrm{MgFe}_{2} \mathrm{O}_{4}$ and $\mathrm{MgFeO}$. The experimental elemental mass percentages of $\mathrm{Mg}, \mathrm{Fe}$ and $\mathrm{O}$ are $12.1 \%, 47.8 \%$ and $40.1 \%$, respectively. Using equation 10, the mass percentages of $\mathrm{MgFe}_{2} \mathrm{O}_{4}$ are theoretically calculated to be $12.15 \%, 55.85 \%$ and $32 \%$, whereas those of $\mathrm{MgFeO}$ are $25 \%, 58.3 \%$ and 16.7\%. The mass percentages of $\mathrm{Fe}$ and $\mathrm{O}$ in $\mathrm{Fe}_{3} \mathrm{O}_{4}$ compounds are $72.4 \%$ and $27.6 \%$, respectively. Therefore, the successful synthesis of the $\mathrm{MgFe}_{2} \mathrm{O}_{4}$ compound is confirmed by the similarities between the mass percentages obtained in this study and the theoretical values for $\mathrm{MgFe}_{2} \mathrm{O}_{4}$.
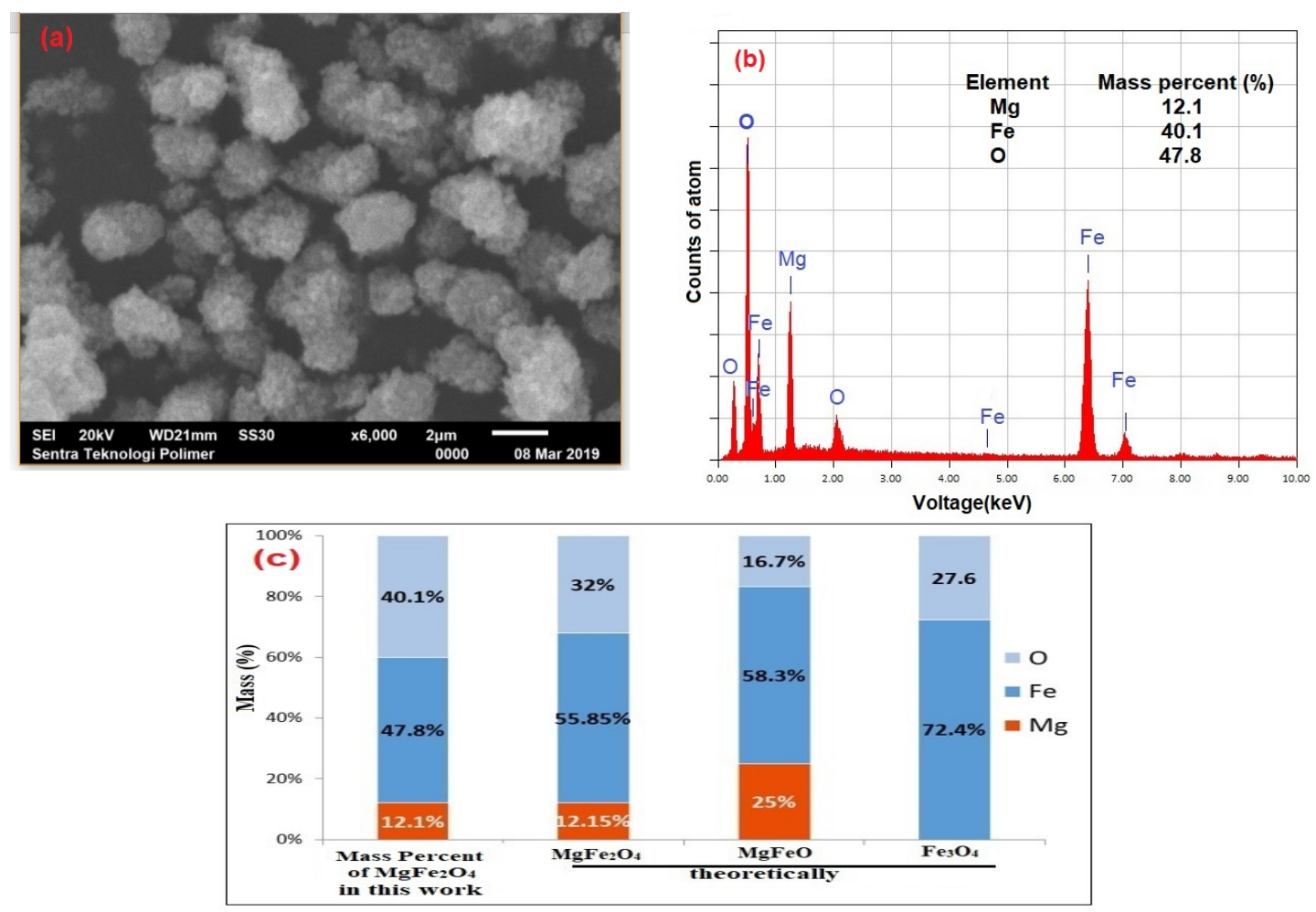

Fig.-3: (a) SEM and (b) SEM-EDX Results and (c) Percent Mass Graph for $\mathrm{MgFe}_{2} \mathrm{O}_{4}$

\section{TEM Analysis of $\mathrm{MgFe}_{2} \mathrm{O}_{4}$}

Figure-4a shows that the $\mathrm{MgFe}_{2} \mathrm{O}_{4}$ composite shape is nanospherical, supporting the results of the SEM analysis. In this Fig.-4a, the bright and dark colors indicate single particles and particles that overlap each other, respectively. In addition, the TEM results in Fig.-4b show several $\mathrm{MgFe}_{2} \mathrm{O}_{4}$ particles (red circle), and the average particle size is determined to be approximately $39 \mathrm{~nm}$. 
RASĀYAN J. Chem.

Vol. 13 | No. 1 | 298 - 305| January - March | 2020
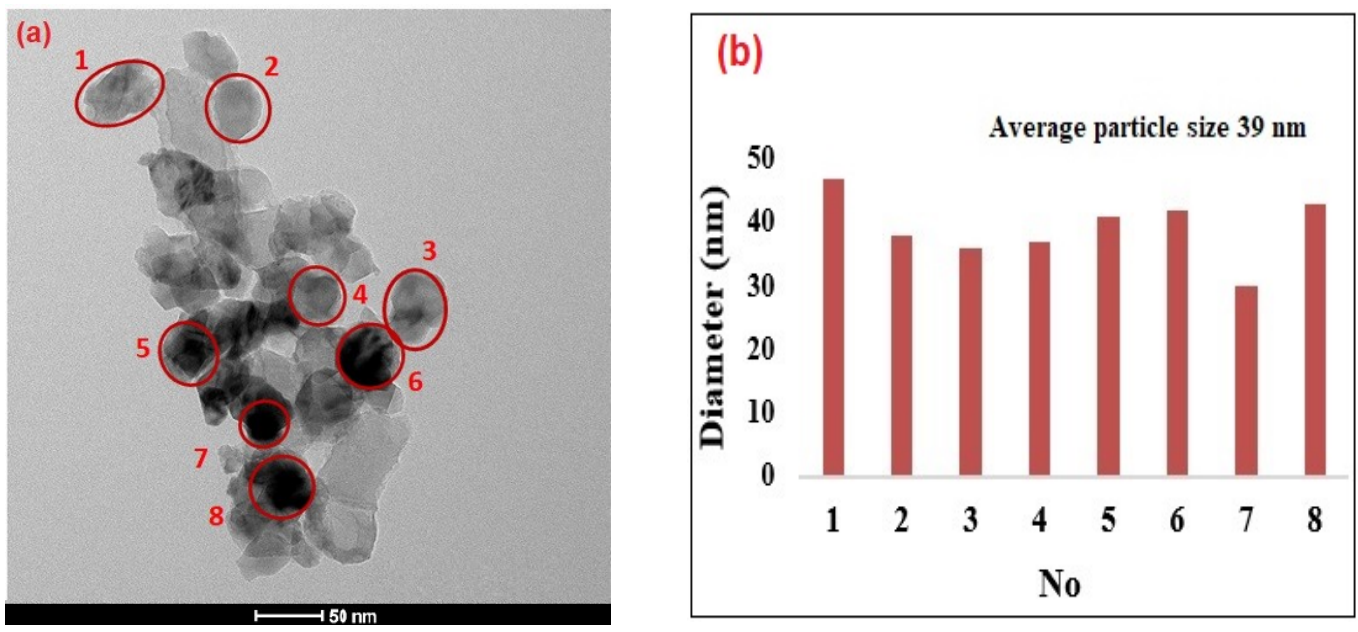

Fig.-4: (a) TEM Results and (b) Average Diameter for $\mathrm{MgFe}_{2} \mathrm{O}_{4}$

\section{Nanocomposite of $\mathrm{MgFe}_{2} \mathrm{O}_{4}-\mathrm{MgO}$}

To prepare the $\mathrm{MgFe}_{2} \mathrm{O}_{4}-\mathrm{MgO}$ nanocomposite with various molar ratios of $\mathrm{MgFe}_{2} \mathrm{O}_{4} / \mathrm{Mg}\left(\mathrm{NO}_{3}\right)_{2}$ (1: 1, 1: 2, 1: 3), $\mathrm{Mg}\left(\mathrm{NO}_{3}\right)_{2}$ was added to the best $\mathrm{MgFe}_{2} \mathrm{O}_{4}$ particles.

\section{FTIR Analysis of $\mathrm{MgFe}_{2} \mathrm{O}_{4}-\mathrm{MgO}$}

Figure-5 shows the spectra of $\mathrm{MgFe}_{2} \mathrm{O}_{4}-\mathrm{MgO}$ with ratios of 1: 1 (Fig.-5a), 1: 2 (Fig.-5b) and 1: 3 (Fig.5c). The peak of approximately $475-700 \mathrm{~cm}^{-1}$ corresponds to the wavenumbers of $\mathrm{Mg}-\mathrm{O}$ and $\mathrm{Fe}-\mathrm{O}$ inorganic compounds and is observed in all the spectra in Fig.-5. The other peaks are attributed to the precursors remaining after the calcination process in the furnace. The peak at $1450 \mathrm{~cm}^{-1}$ is due to $\mathrm{NO}_{3}$ groups. In the three spectra, the peak at $3707 \mathrm{~cm}^{-1}$ is attributed to the $\mathrm{OH}$ stretching of the residual $\mathrm{Mg}(\mathrm{OH})_{2}$ that does not decompose into $\mathrm{MgO}$. This peak is lower in Fig.-5b and 5c, indicating that molar ratios of $1: 2$ and $1: 3$ are better than a molar ratio of $1: 1$.

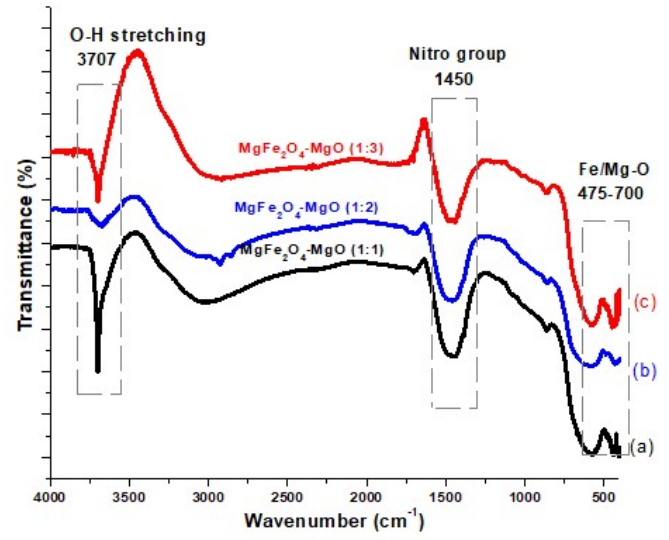

Fig.-5: FTIR Spectra of $\mathrm{MgFe}_{2} \mathrm{O}_{4}-\mathrm{MgO}$

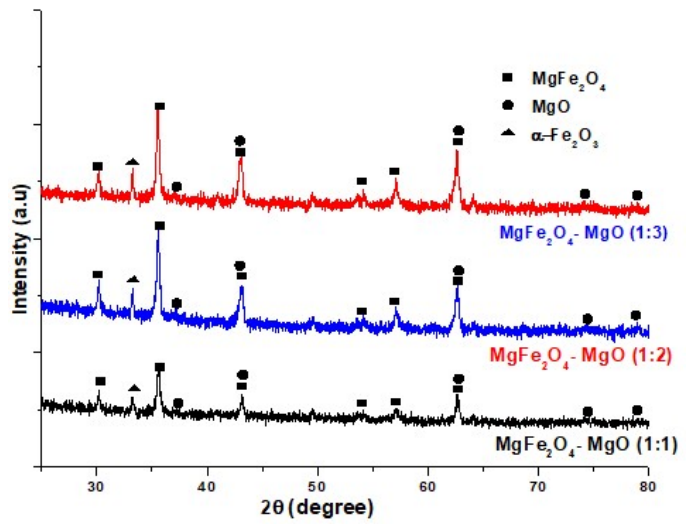

Fig.-6: XRD Patterns of $\mathrm{MgFe}_{2} \mathrm{O}_{4}-\mathrm{MgO}$

\section{XRD Analysis of $\mathrm{MgFe}_{2} \mathrm{O}_{4}-\mathrm{MgO}$}

Figure-6 shows the XRD patterns of $\mathrm{MgFe}_{2} \mathrm{O}_{4}-\mathrm{MgO}$ with various molar ratios of $\mathrm{MgFe}_{2} \mathrm{O}_{4}$ to $\mathrm{MgO}$ (1: 1 , 1: 2 and 1: 3). As shown in Fig.-6, the $\mathrm{MgFe}_{2} \mathrm{O}_{4}-\mathrm{MgO}$ diffraction patterns for all the molar ratios have $2 \theta$ peaks at 30.2, 33.2, 35.5, 43.3, 54.1, 57.0, and 62.6 (square shape), similarly to JCPDS 01-073-2211 for the crystalline phase of $\mathrm{MgFe}_{2} \mathrm{O}_{4}$. The peaks confirming the formation of $\mathrm{MgFe}_{2} \mathrm{O}_{4}-\mathrm{MgO}$ composites are only observed at ratios of $1: 2$ and $1: 3$; the $2 \theta$ peaks at $37.0,43.0,62.4,74.8$ and $78.7^{\circ}$ (sphere shape) are specific to $\mathrm{MgO}$, according to JCPDS 01-077-2364. These results demonstrate the successful formation of 
RASĀYAN J. Chem.

Vol. 13 | No. 1 |298 - 305| January - March | 2020

$\mathrm{MgFe}_{2} \mathrm{O}_{4}-\mathrm{MgO}$ nanocomposites with ratios of 1: 2 and 1:3. Meanwhile, $\mathrm{MgFe}_{2} \mathrm{O}_{4}-\mathrm{MgO}$ with a ratio of 1: 1 does not exhibit the peaks specific to $\mathrm{MgO}$. The diffraction patterns for all the molar ratios also have a $2 \theta$ peak at $33.2^{\circ}$ (triangle shape) corresponding to $\alpha-\mathrm{Fe}_{2} \mathrm{O}_{3}$, according to JCPDS 01-080-2377.

\section{SEM Mapping Analysis of $\mathrm{MgFe}_{2} \mathrm{O}_{4}-\mathrm{MgO}$}

To determine the distribution of each element in the synthesized composite, SEM mapping analysis was performed, as shown in Fig.-7. This image shows the distributions of $\mathrm{Mg}$ (Fig.-7a), Fe (Fig.-7b), and O (Fig.-7c), and Fig.-7d presents the SEM image of $\mathrm{MgFe}_{2} \mathrm{O}_{4}-\mathrm{MgO}$ with no color. Figure-7 shows that $\mathrm{Mg}$, $\mathrm{Fe}$ and $\mathrm{O}$ are evenly distributed across the entire surface of the sample or mingle with each other. This means that $\mathrm{MgO}$ is distributed on the surface of the $\mathrm{MgFe}_{2} \mathrm{O}_{4}$ catalyst support. This result shows that $\mathrm{MgFe}_{2} \mathrm{O}_{4}$ and $\mathrm{MgO}$ are successfully and well composited.
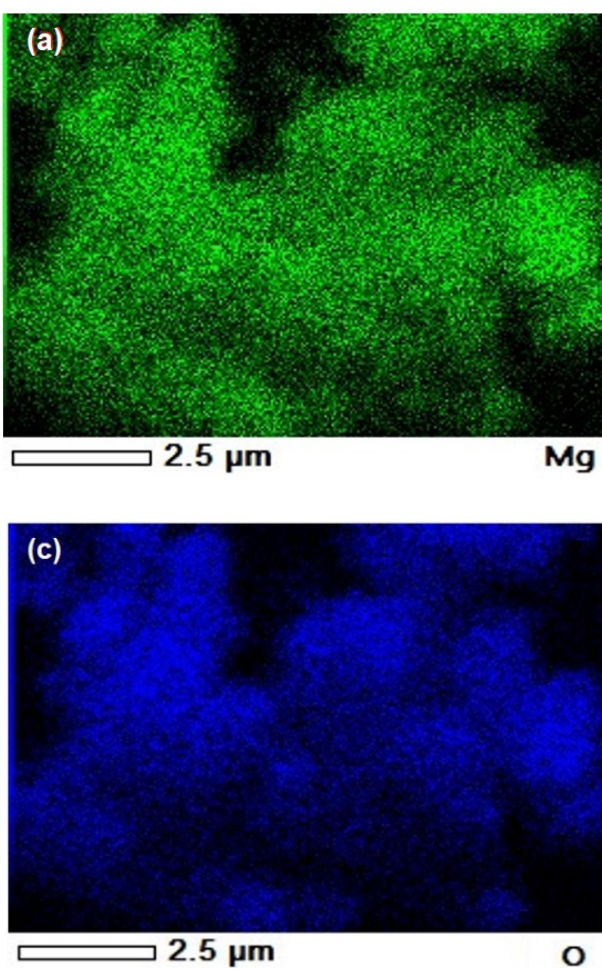
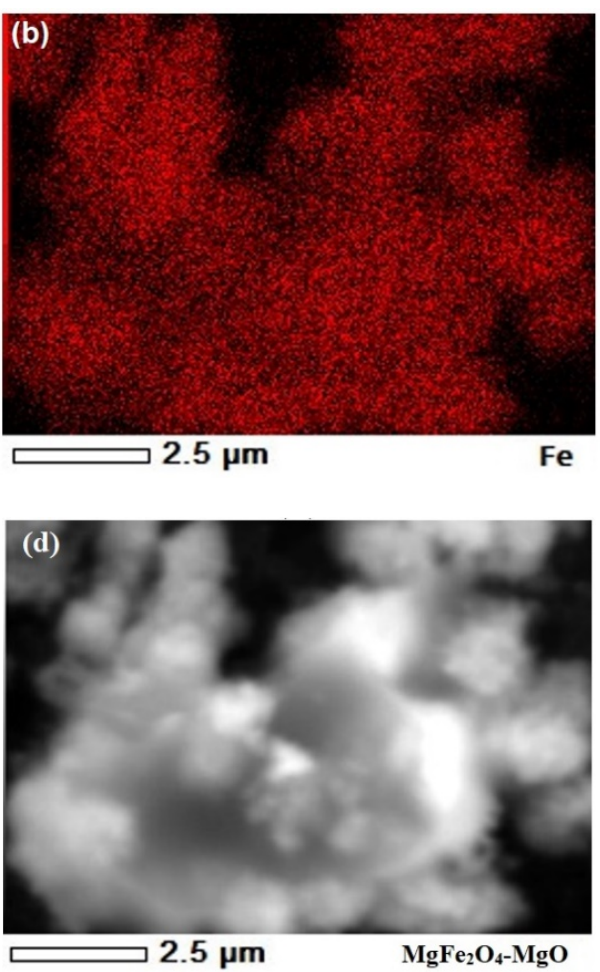

Fig.-7: SEM Mapping of $\mathrm{MgFe}_{2} \mathrm{O}_{4}-\mathrm{MgO}$ Showing the Distributions of (a) $\mathrm{Mg}$, (b) Fe, and (c) $\mathrm{O}$ and (d) the Morphology of $\mathrm{MgFe}_{2} \mathrm{O}_{4}-\mathrm{MgO}$

\section{TEM Analysis of $\mathrm{MgFe}_{2} \mathrm{O}_{4}-\mathrm{MgO}$}

Figure-8a shows that the shape of the $\mathrm{MgFe}_{2} \mathrm{O}_{4}-\mathrm{MgO}$ nanocomposite varies and the average particle size is $50 \mathrm{~nm}$. In Fig.-8, bright and dark colors are observed and are attributed to single particles and particles that overlap each other, respectively. The TEM results in Fig.-8b are obtained from several $\mathrm{MgFe}_{2} \mathrm{O}_{4}$ particles (red circle), and the average particle size is determined to be approximately $50 \mathrm{~nm}$.

\section{Catalytic Activity of the $\mathrm{MgFe}_{2} \mathrm{O}_{4}-\mathrm{MgO}$ Nanocomposite in an Esterification Reaction}

In this study, $\mathrm{MgFe}_{2} \mathrm{O}_{4}-\mathrm{MgO}$ was synthesized with various molar ratios of $\mathrm{MgFe}_{2} \mathrm{O}_{4}$ to $\mathrm{MgO}$ (1: 1, 1: 2 and 1: 3.) to optimize the amount of $\mathrm{MgO}$ used in the nanocomposite synthesis for catalysis. The conversion was determined using equations 1 and 2 and is plotted as a function of the molar ratio of $\mathrm{MgFe}_{2} \mathrm{O}_{4} / \mathrm{MgO}$ in Fig.-9.

Figure-9 shows that using $\mathrm{MgFe}_{2} \mathrm{O}_{4} / \mathrm{MgO}$ with a molar ratio of 1: 1 results in a percent conversion to biodiesel of $71.557 \%$. When the ratio is $1: 2$, the percent conversion to biodiesel increases to $96.089 \%$. This result shows that the addition of $\mathrm{MgO}$ to the composite increases the percent conversion of the catalyst, because $\mathrm{MgO}$ functions as the basic active site of the catalyst, and the collision of the reactants 
RASĀYAN J. Chem.

Vol. 13 | No. 1 |298 - 305| January - March | 2020

with the catalyst is more effective, increasing the activity of the catalyst. However, when the molar ratio is $1: 3$, the conversion is $96.160 \%$, and the percent increase in the biodiesel conversion is not significant. Therefore, the optimal percent conversion is obtained at a 1:2 $\mathrm{MgFe}_{2} \mathrm{O}_{4}$ to $\mathrm{MgO}$ molar ratio. The percent conversion obtained in this study is higher than the results of previous studies ${ }^{14,19}$.

The best $\mathrm{MgFe}_{2} \mathrm{O}_{4}-\mathrm{MgO}$ nanocomposite, which has a molar ratio of 1: 2, as compared to $\mathrm{MgO}$ and $\mathrm{MgFe}_{2} \mathrm{O}_{4}$ to determine the role of each component. Figure-10 shows the percent conversion to biodiesel for the different catalyst types. The biodiesel percent conversions obtained with $\mathrm{MgO}$ and $\mathrm{MgFe}_{2} \mathrm{O}_{4}$ are $71.031 \%$ and $39.68 \%$, respectively. These results show that $\mathrm{MgO}$ acts as the basic active site of the catalyst, whereas $\mathrm{MgFe}_{2} \mathrm{O}_{4}$ functions as an auxiliary catalyst; therefore, combining them in a $\mathrm{MgFe}_{2} \mathrm{O}_{4^{-}}$ $\mathrm{MgO}$ nanocomposite increases the catalytic activity to $96.089 \%$.

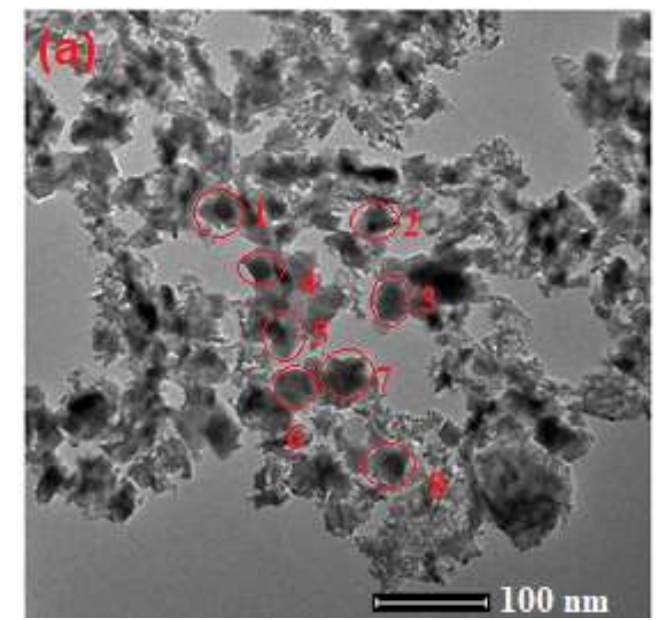

(a)

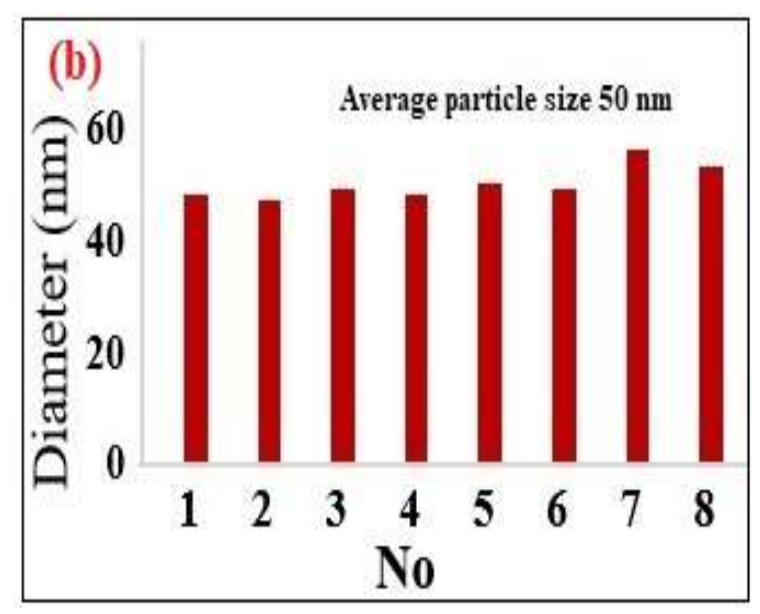

(b)

Fig.-8: TEM results Results and (b) Average Diameter for $\mathrm{MgFe}_{2} \mathrm{O}_{4}-\mathrm{MgO}$

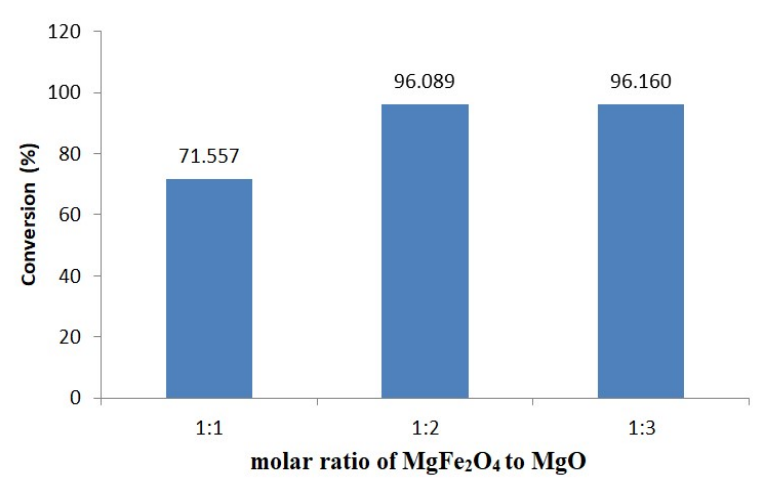

Fig.-9: Percent Conversion to Biodiesel at Different Molar Ratios

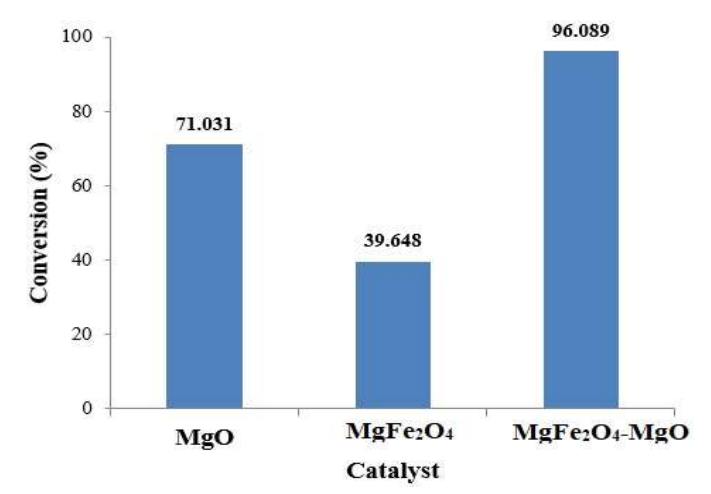

Fig.-10: Percent Conversion to Biodiesel for Different Catalyst Types

\section{CONCLUSION}

A nanocomposite of $\mathrm{MgFe}_{2} \mathrm{O}_{4}-\mathrm{MgO}$ was successfully synthesized and used as a catalyst in the esterification of oleic acid to biodiesel. In the first stage, $\mathrm{MgFe}_{2} \mathrm{O}_{4}$ was synthesized by a ball-milling mechanochemical method with the optimal results obtained at a calcination temperature of $750^{\circ} \mathrm{C}$. The results of the FTIR characterization reveal the presence of peaks with wavenumbers corresponding to $\mathrm{Mg}$ $\mathrm{O}$ and $\mathrm{Fe}-\mathrm{O}$ bonds in the range of $500-900 \mathrm{~cm}^{-1}$. The XRD results show that the structure is a crystalline phase, the SEM results reveal nanospherical shapes, and TEM indicates average size of approximately 39 $\mathrm{nm}$. The $\mathrm{MgFe}_{2} \mathrm{O}_{4}-\mathrm{MgO}$ nanocomposite was successfully synthesized, and the average particle size obtained by TEM is approximately $50 \mathrm{~nm}$. The catalytic activity in oleic acid esterification to methyl ester 
RASĀYAN J. Chem.

Vol. 13 | No. 1 | 298 - 305| January - March | 2020

biodiesel was studied. The best $\mathrm{MgFe}_{2} \mathrm{O}_{4}-\mathrm{MgO}$ nanocomposite has a molar ratio of 1:2 and gives a percent conversion of $96.089 \%$.

\section{ACKNOWLEDGMENT}

This work was supported by grants from Universitas Indonesia through PITTA A: NKB0439/UN2.R3.1/HKP.05.00/2019.

\section{REFERENCES}

1. M.D. Putra, M. C. Irawan, Udiantoro, Y. Ristianingsih, I. F. Nata, Journal of Cleaner Production, 195, 1249(2018), DOI:10.1016/j.jclepro.2018.06.010

2. Helmiyati, Y. Anggraini, International Journal of Technology, 10(4), 116(2019), DOI: 10.14716/ijtech. v10i4.2597

3. M. Prabhahar, S. Sendilvelan, S. Prakash, M. Saravanakumar, Rasayan Journal of Chemistry, 10(4), 1075(2017), DOI:10.7324/RJC.2017.1041847

4. H. Zhang, H. Li, H. Pan, A. Wang, S. Souzanchi, C. Xu, S. Yang, Applied Energy, 223, 416(2018), DOI:10.1016/j.apenergy.2018.04.061

5. M.R. Santos, M.V.R. Rodrigues, A.B.S. Santos, M.G. Valerio, G.B.C. Martins, R.R. Sucupira, L. Meneghetti, P.A.Z. Suarez, Journal of Molecular Catalysis A: Chemical, 422, 131(2016), DOI: 10.1016/j.molcata.2016.01.009

6. S. Alaei, M. Haghighia, J. Toghiani, B. R. Vahid, Industrial Crops and Products, 117, 322(2018), DOI: $10.1016 /$ j.indcrop.2018.03.015

7. S. Dawood, M. Ahmad, K. Ullah, M. Zafar, K. Khan, Materials Research Bulletin, 101, 371(2018), DOI:10.1016/j.materresbull.2018.01.047

8. F. Lu, W. Yu, X. Yu, S-T. Tu, Energy Procedia, 75, 72(2015), DOI:10.1016/j.egypro.2015.07.140

9. I. Fatimah, D. Rubiyanto, A. Taushiyah, F.B. Najah, U. Azmi, Y. Sim, Sustainable Chemistry and Pharmacy, 12, 100129(2019), DOI:10.1016/j.scp.2019.100129

10. J.L. Sihombing, A.N. Pulungan, M. Zubir, Jasmidi, A.A. Wibowo, S. Gea, B. Wirjosentono, Y.A. Hutapea, Rasayan Journal of Chemistry, 12(1), 205(2019), DOI:10.31788/RJC.2019.1215036

11. S. Tang, L. Wang, Y. Zhang, S. Li, S. Tian, B. Wang, Fuel Processing Technology, 95, 84(2012), DOI: 10.1016/j.fuproc.2011.11.022

12. H.M. Awad, A. El-Maghraby, Rasayan Journal of Chemistry, 11(3), 1320(2018), DOI: 10.31788/RJC.2018.1133086

13. V. Chaudhary, Y. Zhong, H. Parmar, V. Sharma, X. Tan, R.V. Ramanujan, Chemistry Open, 7(8), 590(2018), DOI:10.1002/open.201800091

14. H. Helmiyati, R.P. Suci, AIP Conference Proceedings, 2168, 020063(2019), DOI: $10.1063 / 1.5132490$

15. H.R.H. Hebbar, M.C. Math, K.V. Yatish, Energy, 143, 25(2018), DOI: 10.1016/j.energy.2017.10.118

16. H. Helmiyati, I. Masriah, AIP Conference Proceedings, 2168,020062(2019), DOI: $10.1063 / 1.5132489$

17. Y. Zu, Y. Zhao, K. Xu, Y. Tong, F. Zhao, Ceramics International, 42(16), 18844(2016), DOI: 10.1016/j.ceramint.2016.09.030

18. W. Wang, B. Liu, K. Xu, Y. Zu, J. Song, F. Zhao, Ceramics International, 44(15), 19016(2018), DOI: $10.1016 /$ j.ceramint.2018.07.145

19. Q. Shu, W. Zou, J. He, H. Lesmana, C. Zhang, L. Zou, Y. Wang, Renewable Energy, 135, 836(2019), DOI: $10.1016 /$ j.renene.2018.12.067

[RJC- 5497/2019] 